\title{
Forecasting of Cashew Area Harvested, Yield and Production Using Trend Analysis
}

\author{
Okeke Daniel Chukwujioke ${ }^{1}$, Akarue Blessing Okiemute ${ }^{2}$ \\ ${ }^{1}$ Department of Agricultural Science Education, Nwafor Orizu College of Education, Nsugbe, Nigeria \\ ${ }^{2}$ Department of Agricultural Science Education, College of Education, Warri, Nigeria
}

Email address:

olisdon@yahoo.com (O. D. Chukwujioke), blessingakarue4edu@gmail.com (A. B. Okiemute)

\section{To cite this article:}

Okeke Daniel Chukwujioke, Akarue Blessing Okiemute. Forecasting of Cashew Area Harvested, Yield and Production Using Trend Analysis. International Journal of Agricultural Economics. Special Issue: Academic Research for Multidisciplinary.

Vol. 3, No. 4, 2018, pp. 65-71. doi: 10.11648/j.ijae.20180304.11

Received: April 18, 2018; Accepted: June 20, 2018; Published: July 7, 2018

\begin{abstract}
The study was conducted to examine the trend analysis of area, yield and production for Cashew in Nigeria. The findings of the study are based on data from the years (1961 to 2016) and was taken from the database of FAO (2018). Three Models of trend analysis were applied. The models were Linear Trend Model, Quadratic Trend Model, and cubic trend Model. The most appropriate Model for trend analysis of the present study was Cubic Trend Model based on the highest $\mathrm{R}^{2}$ of $(95.76 \%),(95.76 \%)$ and $(88.12 \%)$ for cashew area harvested, production and yield respectively, coupled with the lowest residual sum square and mean square error. Forecasting of the data was done up to 2026. The forecasted values were area harvested $(409459.07 \mathrm{ha}-486296.12)$, yield $(24272.09 \mathrm{hg} / \mathrm{ha}-27422.91 \mathrm{hg} / \mathrm{ha})$ and production $(990382.68$ tons-1.127E +06$)$. The study presents an insight to national policy makers regarding this essential crop and provides them with a reference range of values in area harvested, yield and production in future so that they may be able to effectively deal with cashew production in Nigeria.
\end{abstract}

Keywords: Cashew, Area Harvested, Yield, Production, Cubic Trend Model, RSS, MSE, Nigeria

\section{Introduction}

Agriculture in Nigeria is believed to be the basis of livelihood and development for all mankind. Nigeria as a developing nation with most of the population still involved in agriculture as a major source of income. Major aspects of agricultural production in Nigeria include activities such as processing, distribution, and marketing of crop and animal products. Agboola [2] noted that there is no doubt that agriculture remains the leading non-oil sector of Nigeria economy, with about $60-70 \%$ of the population engaged in it and providing about $70 \%$ of non-petroleum exports which is about $10 \%$ of the total national exports

Tunji [20], on his part, noted that Nigeria ranks sixth worldwide and first in Africa continent in the area of agricultural product output: Despite the fact that it has suffered from poor management, poor government policies, use of improved seeds and seedlings, lack of fertilizers, neglect and the lack of basic infrastructural facilities such as feeder roads, water supply, electricity, schools, health etc, the sector still accounts for over $38.01 \%$ of the nation's GDP as well as providing a large proportion of the people with employment.

In the 1970s, Africa was the largest producer of raw cashew nuts accounting for $67.5 \%$ of world production. There was a decline by 2000 to $35.6 \%$, with the largest producers being Nigeria, Tanzania, and Mozambique. [7].

According to Olagunju [13], Nigeria is said to be one of the top ten cashew producers in the world. It is a smallholder crop and provides supplementary incomes to thousands of farmers across major producing States. A large number of people mostly in low-income groups generate an income from cashew as harvesters, local merchants (Local/Licensed Buying Agents -LBAs) and workers associated with LBAs, transporters, processors, and exporters. Her interest in cashew nut production began in the early 1950's when the plantations were introduced in Kogi, Anambra, Imo, Enugu, Oyo and Osun states.

The major objective for this study was to focus on past and 
future trends of cashew area harvested, yield and production in Nigeria by using appropriate forecasting and trend analysis model. Growth models can provide a fitting data summary and be used for the forecast in any other field. Khin et al. [11] studied the forecasting of natural rubber price in the world market; They used different econometric models to forecast the short-run monthly prices and also to determine the interrelationships between Natural Rubber production, consumption and prices. The results indicate that MARMA's ex-post forecasts are more efficient in terms of its statistical criteria.

Assis et al. [3] conducted a forecasting analysis on cocoa bean prices in Malaysia. Their main aim of the research was to compare the forecasting performances of four different time series methods using monthly average data from January 1992 - December 2006. The selection criteria used was the mean absolute percentage error (MAPE) Root mean squared error, (RMSE), mean absolute error (MAE) and Theil's inequality coefficient (U-STATISTICS). This study indicated that the mixed ARIMA/GARCH model was adjudged the best.

Srinivasulu and Srinivasa Rao [18] employed various regression equation models in analysing the growth rates of turmeric and estimated the future projections up to $2020 \mathrm{AD}$. Finger, [7], Karim et al., [10] and Rimi et al., [16] used the linear trend model. Dhakre and Amod Sharma [5] carried out a study on the growth rates of area, production and productivity of Ginger in north-eastern region of India using exponential growth model. However, Tahir and Habib [19] used four trend equations namely the linear, Quadratic, exponential and S-curve model in forecasting of maize area and production in Pakistan. Rajan, Palanivel and mohan, [14] also used the trend analysis to check for cotton area, production and Productivity in Tamil Nadu. In this study estimation was made using various models, this we believe will be useful for policy makers in taking policy decisions.

Objectives.

The specific objectives of the study are as follows,

1. To study the trend and growth of area, yield and production of Cashew in Nigeria.

2. To examine the contribution of area, production and productivity both are increasing the magnitude for the cashew crop.

3. To make forecast for the next ten years.

\section{Materials and Methods}

The study was conducted by using time series data of Cashew area harvested, yield and production during the years 1961 to 2016 (56 years) of Nigeria. The data was collected from the Food and Agriculture Statistics [6]. Data was analyzed by using MINITAB 17, excel and Eview 8 software. The study employed three forecasting methods which are Linear, Quadratic, and Cubic Models. For trend analysis, equation as proposed by Boken [4] Finger [7], Rimi et al. [16], and Tahir and Habib [19] Rajan, et.al [14] was utilized. The methodology followed is through trend analysis.

\subsection{Linear Equation}

$$
\mathrm{Yt}=\mathrm{b}_{0}+\mathrm{b}_{1} \mathrm{X}+\mathrm{e}_{\mathrm{x}}
$$

$\mathrm{Yt}=$ Area harvested, Yield and production in year $\mathrm{t}$

$\mathrm{b}_{0}=$ Constant

$\mathrm{b}_{1}=$ Regression coefficient

$\mathrm{X}=$ Time period (years),

$\mathrm{e}_{\mathrm{x}}=$ Exponent function

\subsection{Quadratic Equation}

The quadratic trend model is known to account for simple curvature in the data and it is presented as:

$$
\mathrm{Y}_{\mathrm{t}}=\mathrm{b}_{0}+\mathrm{b}_{1} * \mathrm{X}+\mathrm{b}_{2} \mathrm{X}^{2}+\mathrm{e}_{\mathrm{x}}
$$

\subsection{Cubic Model}

The cubic trend model is presented as follows:

$$
\mathrm{Y}_{\mathrm{t}}=\mathrm{b}_{0}+\mathrm{b}_{1} * \mathrm{X}+\mathrm{b}_{2} \mathrm{X}^{2}+\mathrm{b}_{3} \mathrm{X}^{3}+\mathrm{e}_{\mathrm{x}}
$$

\begin{tabular}{|c|c|c|c|}
\hline $\mathbf{S} / \mathbf{N}$ & Models & Equations & Explanation \\
\hline 1 & Linear & $\mathrm{Yt}=\mathrm{b}_{0}+\mathrm{b}_{1} \mathrm{X}+\mathrm{e}_{\mathrm{x}}$ & $\begin{array}{l}\mathrm{Y}=\text { is Area harvested, Yield and production, and } \mathrm{X}_{\mathrm{i}}=\text { Time period respectively, } \mathrm{b}_{0}, \mathrm{~b}_{1} \text { is } \\
\text { constants to be an estimated. }\end{array}$ \\
\hline 2 & Quadratic & $\mathrm{Y}_{\mathrm{t}}=\mathrm{b}_{0}+\mathrm{b}_{1} * \mathrm{X}+\mathrm{b}_{2} \mathrm{X}^{2}+\mathrm{e}_{\mathrm{x}}$ & $\begin{array}{l}\mathrm{Y}=\text { is Area harvested, Yield and production, and } \mathrm{X}_{\mathrm{i}}=\text { Time period respectively, } \mathrm{b}_{0}, \mathrm{~b}_{1} \text { is } \\
\text { constants to be an estimated. The quadratic model can be used to model a series that takes off or } \\
\text { a series that dampens. }\end{array}$ \\
\hline 3 & Cubic & $Y_{t}=b_{0}+b_{1} * X+b_{2} X^{2}+b_{3} X^{3}+e_{x}$ & $\begin{array}{l}Y=\text { is Area harvested, Yield and production, and } X_{i}=\text { Time period respectively, } b_{0}, b_{1} \text { is } \\
\text { constants to be an estimated. }\end{array}$ \\
\hline
\end{tabular}

Table 1. Improving Statistical Models to study the Growth Models estimated of Cashew area harvested, yield and production.

\subsection{Accuracy Measures}

Three measures of accuracy were used in this study; these are coefficient of determination $\left(R^{2}\right)$. The $R^{2}$ is the most appropriate for nonlinear statistical model. The range is between 0 and 1, while 0 represent any reasonable model specification and 1 represent a perfect fit. The other two are the Residual sum of square (RSS) which is also known as the sum of square residuals (SSR) or sum of squared errors (SSE) of prediction and the Mean Square Errors or Error Mean Square or Residual Mean Square. The RSS is an amount of the difference between data and an estimated model. In deciding the best model, the model with the highest $\mathrm{R}^{2}$ and smallest values of RSS and MSE indicate the best fitting of the model, thus the best model further yields the minimum error of forecast (Karim et al., [10], and Rajan et al [14]. 


\section{Results}

This section deals with time series data of Area harvested, Yield and production of Cashew in Nigeria and estimated trends in table and figure form of Area harvested, Yield and production in Nigeria are presented.

Previous Trends of Area, Yield and Production of Cashew in Nigeria

The estimated time series parameter of area under Cashew of Nigeria during the year 1961 to 2016 has been presented in Figure 1. Figure 1 show that area harvested of cashew, the result shows a steady growth from 1961 to 1990 and from there an upward trend from the year 1991 to onward to 2016.

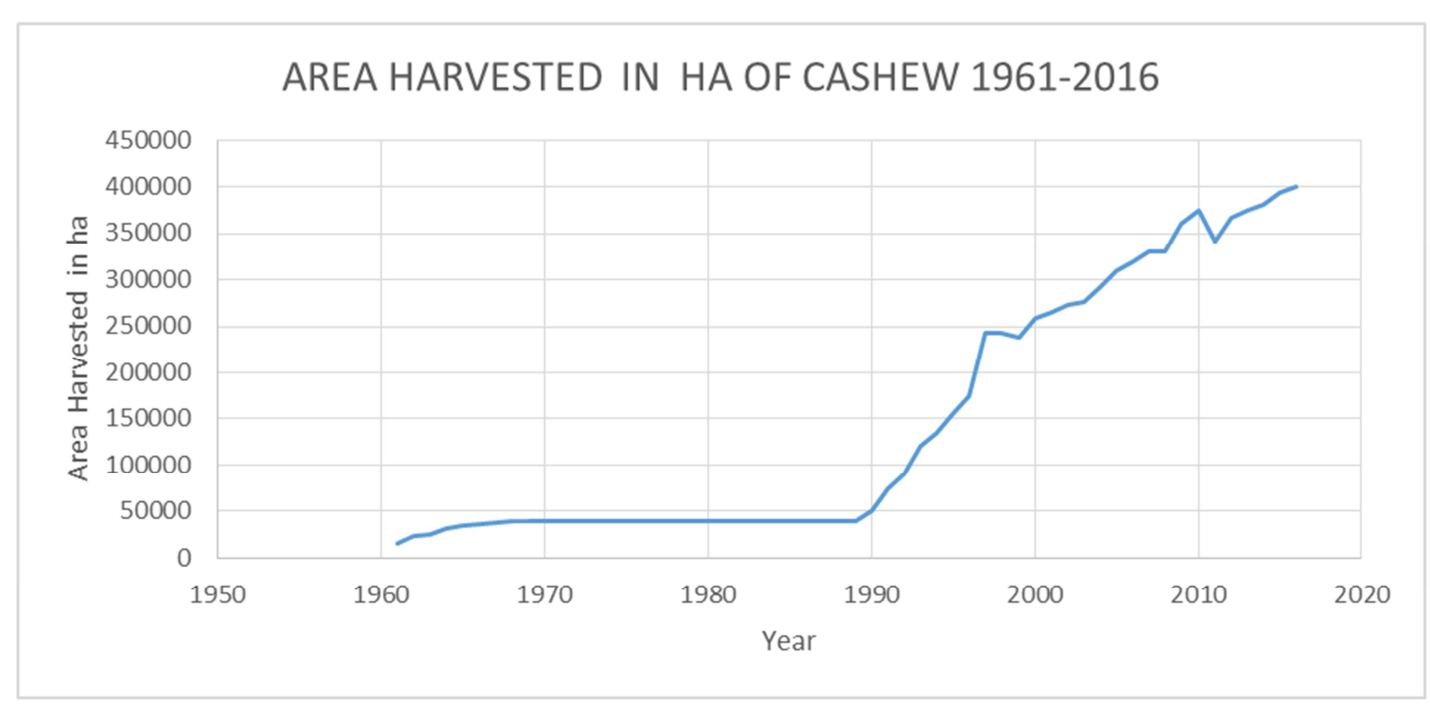

Figure 1. Area Harvested on Cashew in Nigeria 1961-2016.

Figure 2, show a steady growth rate from 1961 to about 1998. The yield gradually increased, following an upward reviewed till year 2000. While from the 2000 onward yield of cashew experienced a continuously increased.

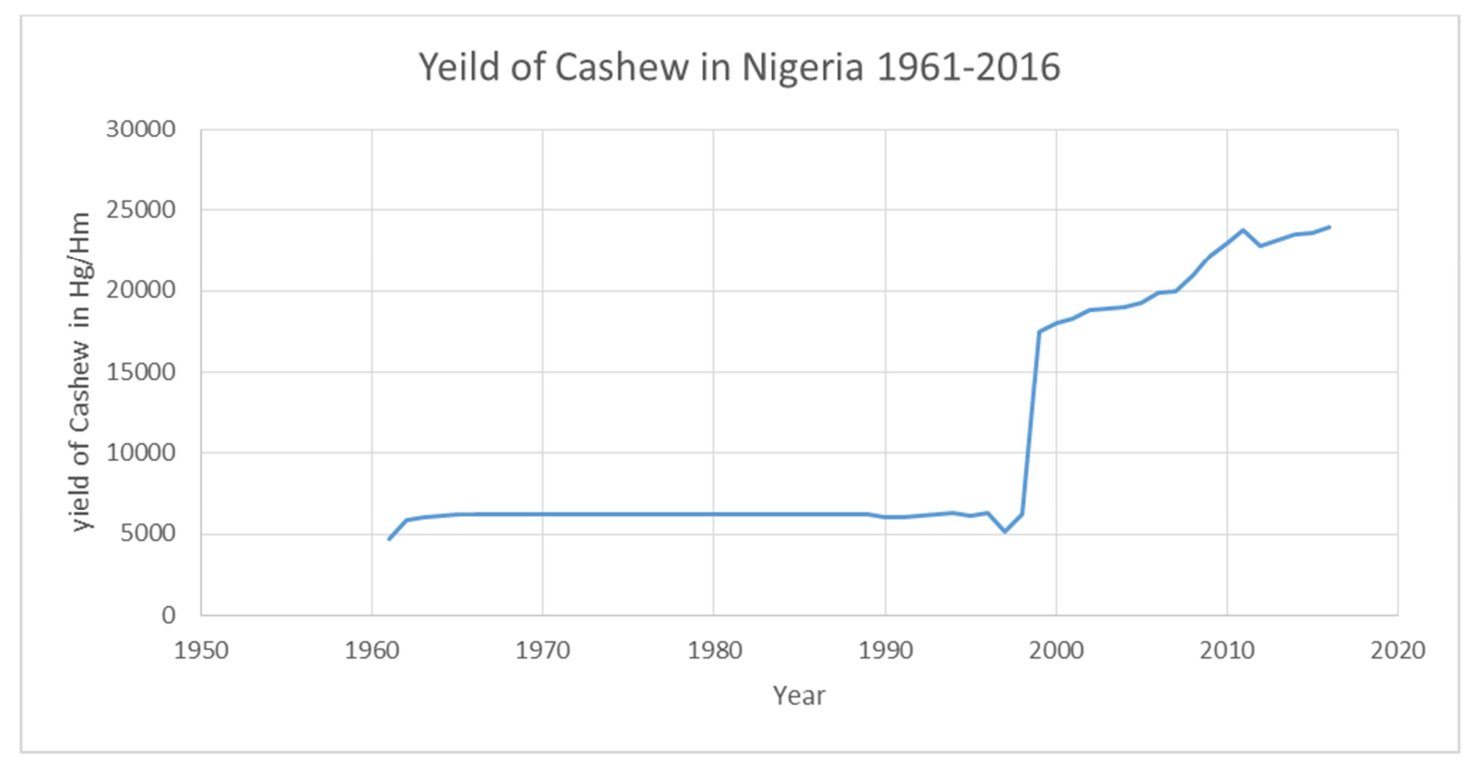

Figure 2. Yield of Cashew in Nigeria 1961-2016.

The issue of cassava production was also analysed using the graphical analysis. The trends depict that production of Cashew was not very impressive from 1961 to 1999, while from 1999 there was an increasing trend in cashew production as depicted in figure 3. The reasons for slower growth of area can be climatic and other economic issues. 


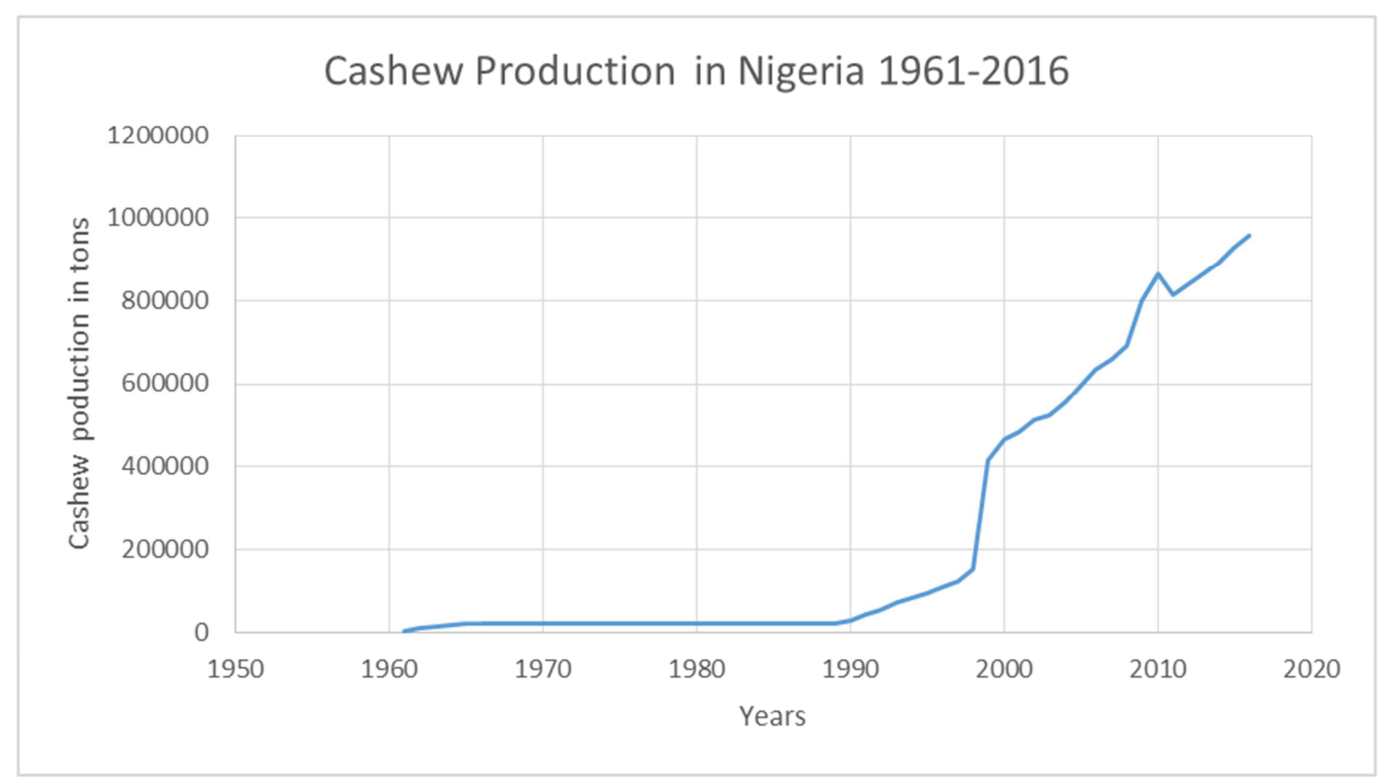

Figure 3. Cashew Production in Nigeria 1961-2016.

Diagnostic Measures for the Selection of Best deterministic growth model for Area, Yield and Production in Nigeria:

This section deals with time series data and estimated trends in Tables and Figures on Cashew on area harvested, yield and production in Nigeria.
The best model of forecasting was chosen based on the results from the three models, the result revealed that all the values of accuracy measures such as the highest $R^{2}$ and smallest RSS and MSE in Table 2, the cubic trend model was selected as the best model and used for forecasting the future trends of area harvested.

Table 2. Growth models of area harvested of Cashew in Nigeria.

\begin{tabular}{llllll}
\hline Model & $\mathbf{R}^{2}$ & Adj. $\mathbf{R}^{2}$ & $\begin{array}{l}\text { Residual Sum of Square } \\
\text { Error }\end{array}$ & $\begin{array}{l}\text { Mean Square } \\
\text { Error }\end{array}$ & Trend Equation \\
\hline Linear & 0.832910 & 0.829816 & $1.70 \mathrm{E}+11$ & 3140278732.000 & $\mathrm{Yt}=-69129+7601 \times \mathrm{t}$ \\
Quadratic & 0.949989 & 0.948102 & $5.08 \mathrm{E}+10$ & 957628183.600 & $\mathrm{Yt}=39541-3641 \times \mathrm{t}+197.2 \times \mathrm{t}^{\wedge} 2$ \\
Cubic & 0.957601 & 0.955155 & $4.30 \mathrm{E}+10$ & 827483435.600 & $\mathrm{Yt}=74132.58-10616.16 \times \mathrm{t}+500.4807 \times \mathrm{t}^{\wedge} 2-3.546868 \times \mathrm{t}^{\wedge} 3$ \\
\hline
\end{tabular}

Source: field Data 2018.

The cubic trend model was selected as the best model for forecasting yield of cashew and was based on the values of accuracy measures such as the highest $\mathrm{R}^{2}$ and smallest RSS and MSE. The result is presented in Table 3.

Table 3. Growth models of yield of Cashew in Nigeria.

\begin{tabular}{llllll}
\hline Model & $\mathbf{R}^{2}$ & Adj. $\mathbf{R}^{\mathbf{2}}$ & $\begin{array}{l}\text { Residual Sum of Square } \\
\text { Error }\end{array}$ & $\begin{array}{l}\text { Mean Square } \\
\text { Error }\end{array}$ & Trend Equation \\
\hline Linear & 0.688 & 0.683 & 861649050.800 & 15956463.900 & $\mathrm{Yt}=613+360.7 \times \mathrm{t}$ \\
Quadratic & 0.881 & 0.877 & 328561960.800 & 6199282.280 & $\mathrm{Yt}=7892-392.3 \times \mathrm{t}+13.21 \times \mathrm{t}^{\wedge} 2$ \\
Cubic & 0.881216 & 0.874363 & $3.28 \mathrm{E}+10$ & 6315146.067 & $\mathrm{Yt}=7727.238--359.1915 \times \mathrm{t}+11.76952 \times \mathrm{t}^{\wedge} 2+0.016851 \mathrm{t}^{\wedge} 3$ \\
\hline
\end{tabular}

Source: field Data 2018.

Table 4 shows the summary of analysis and based on the result as presented in Table 4, the cubic model was chosen as the best model for forecasting production of cashew in
Nigeria. The values of accuracy measures confirm the cubic model to have the highest $\mathrm{R}^{2}$ and smallest RSS and MSE as presented in Table 4.

Table 4. Growth models of production of Cashew in Nigeria.

\begin{tabular}{llllll}
\hline Model & $\mathbf{R}^{2}$ & Adj. $\mathbf{R}^{2}$ & $\begin{array}{l}\text { Residual Sum of } \\
\text { Square Error }\end{array}$ & $\begin{array}{l}\text { Mean Square } \\
\text { Error }\end{array}$ & Trend Equation \\
\hline Linear & 0.731862 & 0.726897 & $1.57 \mathrm{E}+12$ & $2.855 \mathrm{E}+10$ & $\mathrm{Yt}=-69129+7601 \times \mathrm{t}$ \\
Quadratic & 0.955173 & 0.953482 & $2.62 \mathrm{E}+11$ & $4.8377 \mathrm{E}+9$ & $\mathrm{Yt}=39541-3641 \times \mathrm{t}+197.2 \times \mathrm{t}^{\wedge} 2$ \\
Cubic & 0.957601 & 0.955155 & $2.509 \mathrm{E}+11$ & $4.8242 \mathrm{E}+9$ & $\mathrm{Yt}=79923.904-11686.356 \times \mathrm{t}+285.183 \times \mathrm{t}^{\wedge} 2-4.314 \times \mathrm{t}^{\wedge} 3$ \\
\hline
\end{tabular}

Forecasted Cashew Area harvested

The area harvested of cashew shows that the growth rate has positive trend in Nigeria. As figure 4 showed the trend analysis plot for Cashew area harvested in Nigeria by using 
Cubic Trend Model. The blue middle line shows forecasted values of Cashew. As in Table 5 results showed that if the present growth rates of Cashew area remain the same then area of Cashew in Nigeria would be 409459.07, 417996.52, 426533.97, 435071.4., 443608.87, 452146.32, 460683.77,
$469221.22,477758.67$ and 486296.12 ha respectively for the years 2017, 2018, 2019, 2020, 2021, 2022, 2023, 2024, 2025, and 2026. Forecasted values of area harvested under Cashew in Nigeria has slightly increasing trend in coming ten years in Nigeria.

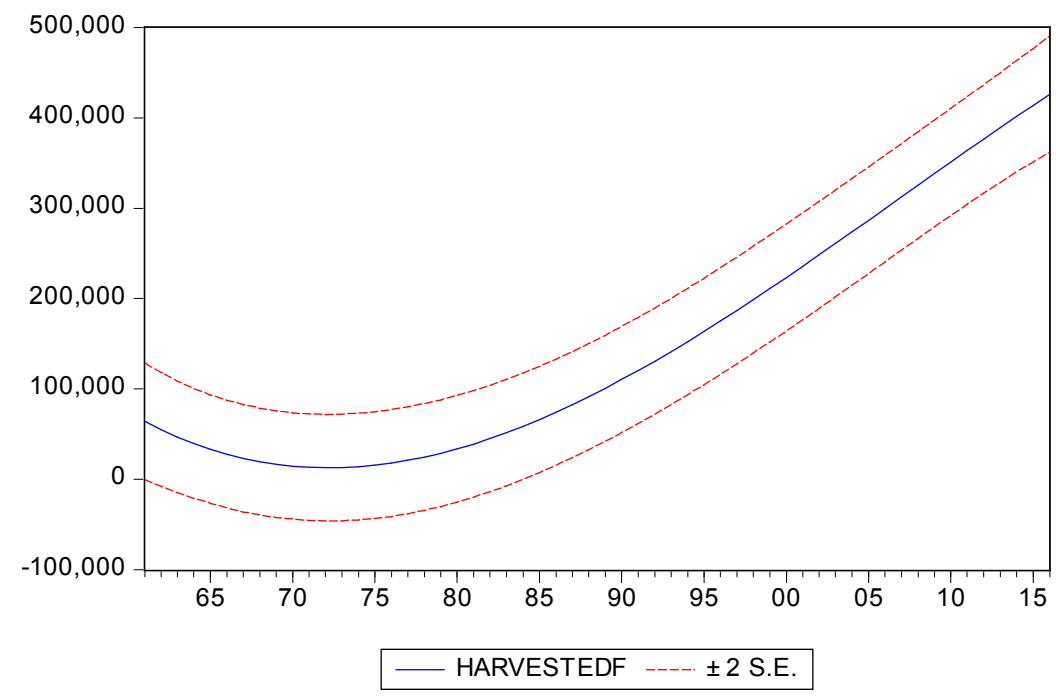

\begin{tabular}{|c|c|}
\hline \multicolumn{2}{|l|}{ Forecast: HARVESTEDF } \\
\hline \multicolumn{2}{|l|}{ Actual: HARVESTED } \\
\hline \multicolumn{2}{|l|}{ Forecast sample: 19612016} \\
\hline \multicolumn{2}{|l|}{ Included observations: 56} \\
\hline Root Mean Squared Error & 27719.62 \\
\hline Mean Absolute Error & 23793.40 \\
\hline Mean Abs. Percent Error & 42.53082 \\
\hline Theil Inequality Coefficient & 0.069740 \\
\hline Bias Proportion & 0.000000 \\
\hline Variance Proportio & 0.010830 \\
\hline Covariance Proportion & 0.989170 \\
\hline
\end{tabular}

Figure 4. Forecasted Cashew area harvested.

Forecasted Cashew Yield:

The yield of cashew also showed a positive trend in Nigeria. This can be seen in figure 5, using the Cubic Trend Model. The blue middle line shows forecasted values of Cashew. As in Table 5 results showed that if the present growth rates of Cashew yield are as follows 24272.09,
$24622.18, \quad 24972.27, \quad 25322.36, \quad 25672.46, \quad 26022.55$, 26372.64, 26722.73, 27072.82 and 27422.91 hg/ha, respectively for the years 2017, 2018, 2019, 2020, 2021, 2022, 2023, 2024, 2025, and 2026. Forecasted values of yield in Nigeria has slightly increasing trend in coming ten years in Nigeria.

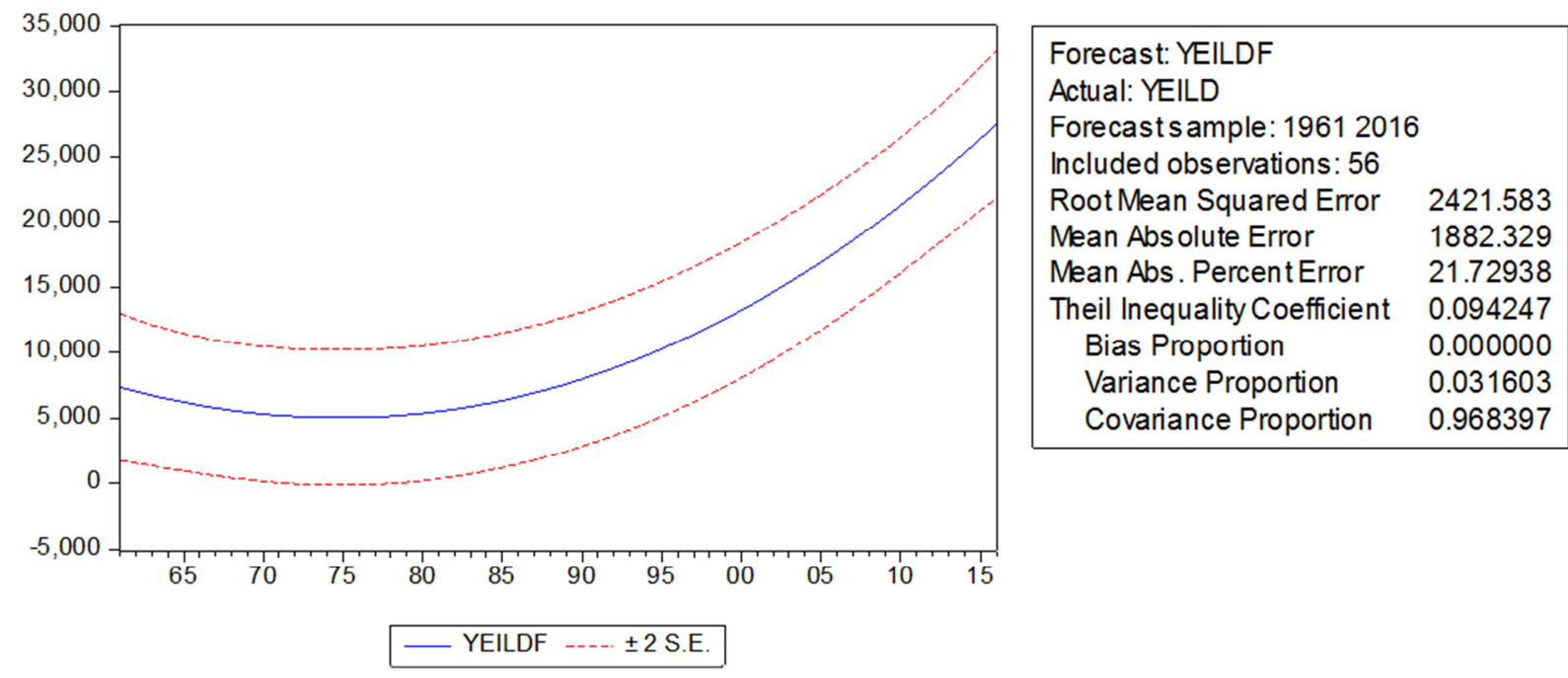

Figure 5. Forecasted Cashew yield.

Forecasted Cashew Production

The production of cashew in tons was also forecasted and it showed a positive trend. Figure 6 showed the trend analysis plot for Cashew production in Nigeria by using Cubic Trend Model. The blue middle line shows forecasted values of Cashew. As in Table 5 results showed that if the present growth rates of Cashew production had a forecasted value of
$990382.68, \quad 1.02 \mathrm{E}+06, \quad 1.05 \mathrm{E}+06, \quad 1.08 \mathrm{E}+06, \quad 1.12 \mathrm{E}+06$, $1.15 \mathrm{E}+06,1.18 \mathrm{E}+06,1.12 \mathrm{E}+06,1.124 \mathrm{E}+06$ and $1.127 \mathrm{E}+06$ tons respectively for the years 2017, 2018, 2019, 2020, 2021, 2022, 2023, 2024, 2025, and 2026. It can also be observed that the forecasted values of production of Cashew in Nigeria has slightly increasing trend in the next ten years. 


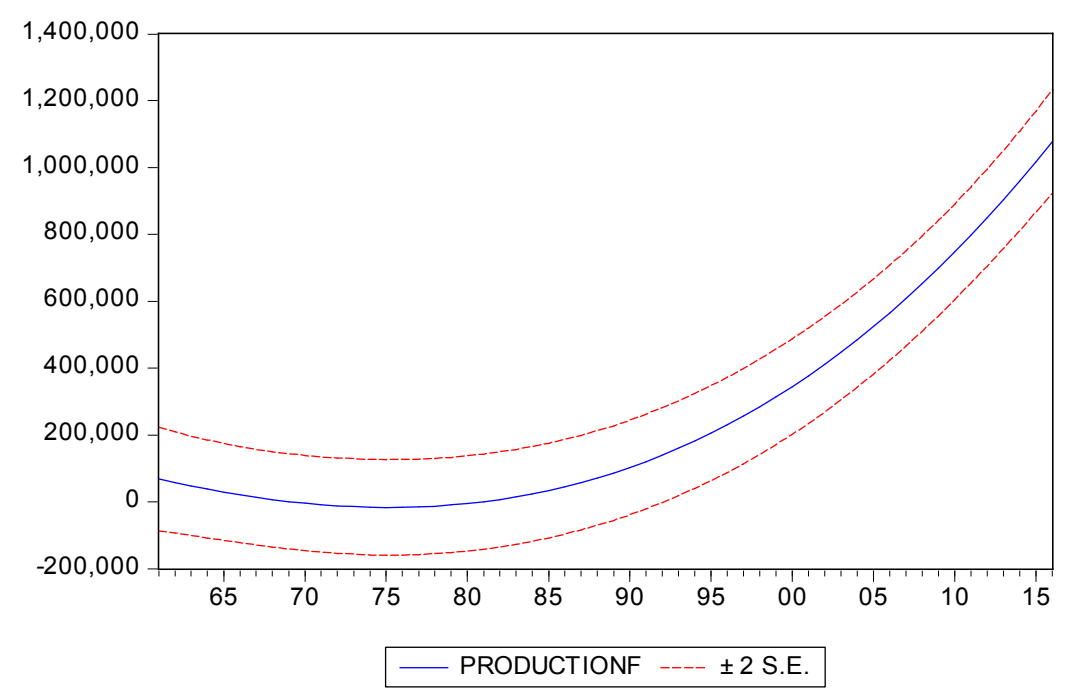

\begin{tabular}{|c|c|}
\hline \multicolumn{2}{|l|}{ Forecast: PRODUCTIONF } \\
\hline \multicolumn{2}{|l|}{ Actual: PRODUCTION } \\
\hline \multicolumn{2}{|l|}{ Forecast sample: 19612016} \\
\hline Root Mean Squared Error & 66930.17 \\
\hline Mean Absolute Error & 55647.61 \\
\hline Mean Abs. Percent Error & 101.7543 \\
\hline Theil Inequality Coefficient & 0.082548 \\
\hline Bias Proportion & 0.000000 \\
\hline Variance Proportion & 0.010955 \\
\hline Covariance Proportion & 0.989045 \\
\hline
\end{tabular}

Figure 6. Forecasted Cashew Production.

Table 5. presents the summary of the forecasted values for area harvested, yield and production of Cashew in Nigeria from 2017 to 2026.

Table 5. Projections of Area Harvested, Production and Yield of Cashew Crop in Nigeria.

\begin{tabular}{llll}
\hline \multirow{2}{*}{ Year } & Area & Production & Yield \\
\cline { 2 - 4 } & (ha) & (Tones) & (Kg/ha) \\
\hline 2017 & 409459.07 & 990382.68 & 24272.09 \\
2018 & 417996.52 & $1.02 \mathrm{E}+06$ & 24622.18 \\
2019 & 426533.97 & $1.05 \mathrm{E}+06$ & 24972.27 \\
2020 & 435071.42 & $1.08 \mathrm{E}+06$ & 25322.36 \\
2021 & 443608.87 & $1.12 \mathrm{E}+06$ & 25672.46 \\
2022 & 452146.32 & $1.15 \mathrm{E}+06$ & 26022.55 \\
2023 & 460683.77 & $1.18 \mathrm{E}+06$ & 26372.64 \\
2024 & 469221.22 & $1.12 \mathrm{E}+06$ & 26722.73 \\
2025 & 477758.67 & $1.124 \mathrm{E}+06$ & 27072.82 \\
2026 & 486296.12 & $1.127 \mathrm{E}+06$ & 27422.91 \\
\hline
\end{tabular}

Table 5 results clearly revealed that there is positive increasing trend for area harvested, production and yield of cashew in Nigeria.

\section{Discussion}

The result from the analysis in figure 1 to figure 3 shows an annual growth in the area harvested, yield and production of cashew in Nigeria under the period reviewed.

Ibrahim, et al. [12] also showed that there was an increase in the growth level of sugarcane production in Nigeria. Similarly, Ramakrishna, et al. [15] also noted with reference to rice production in India that there was positive trend which was also significant at $1 \%$.

With reference to the Diagnostic measure for selecting the best deterministic model, various trend equation has been applied, in this study three trend equation namely - linear, quadratic and cubic were used with the best model being the cubic model. However, this is at variance with Ramakrishna, et al.[15] where the linear model was adjudged the best model for modeling in rice production and productivity while for area plated the logarithmic function was adjudged the best. Similarly, Nazir, et al. [12] found out that the quadratic trend model was the best fitted model for forecasting export of major farm crops (citrus, mango, date and apple) in Pakistan. Abbasi, et al. [1] reported the S-curve model as being the best fitted model for rice and wheat prices in Pakistan. On the forecasted value of cashew, there seems to be an increase in the expected area harvested yield and production as indicated in the analysis as presented in Table 5. A similar increase in area, production and productivity for rice was also advanced in Andhra Pradesh in India [15], and for major fruit export in Pakistan [12].

In the same vein, Sandip [17] also found an increasingly forecasted value for coconut production in Assam using $\operatorname{ARIMA}(2,1,0)$ as the best fitted model.

\section{Conclusion}

The present study used the regression parameter for estimating area harvested, production and yield of cashew in Nigeria. In the course of this study the developed regression model for cashew area harvested, yield and production. The cubic regression model was found to be the best fitted model, with highest $R^{2}$ in area harvested $(95.76 \%)$ production $(95.76 \%)$ and yield $(88.12 \%)$. The lowest residual sum square and mean square error was the selected for minimum value was obtained Table 1, 2, and 3. The future projections of cashew area harvested, yield and production by 2026 were calculated. The projection values were area harvested (409459.07ha -486296.12), yield (24272.09hg/ha $27422.91 \mathrm{hg} / \mathrm{ha}$ ) and production (990382.68tons-1.127E+06 tons). These measures were found to be the best fitted model for projection (Table 3). The authority of the forecasted value can be checked when the data for the lead periods become available. The result of this forecast can be useful for Policy makers on the basis of the projected production, yield and area harvested increase can draw policy and strategy to address the factors affecting this increase in production, yield and area harvested. Furthermore, the study will provide researcher stepping stone for the researchers and economists 
to carry out further investigation that affects the cashew output forecasting for these essential crops in Nigeria.

\section{References}

[1] ABBASI, S. S., TAHIR A, RAZA, I, ABID, S \& KHAN. MN. (2015) Trend analysis and forecasting of wheat and rice prices in Pakistan. Pakistan Journal of Agricultural Research 26(3) 310-317

[2] AgBoolA, A. A. (2012). Essentials of Agricultural Production in Nigeria. Greenline Publishers, Ado-Ekiti, Nigeria pp. 1-2.

[3] ASSIS, K., AMRAN, A., \& REMALI, Y. (2010). Forecasting cocoa bean prices using univariate time series models. Journal of Arts Science and Commerce, 144 (1), 71-80.

[4] BOKEN, V. K. (2000) Forecasting spring wheat yield using time series analysis: A case study for the Canadian Prairies. Agron. J. 92(6): 1047-1053.

[5] DHAKRE AND AMOD SHARMA (2009) Growth and instability analysis of ginger production in North-east: region. Agricultural Situation in India. 463-465.

[6] FAOSTAT (2018) Food and Agriculture Organization of the United Nations. www.fao.org/faostat/en/?

[7] FINGER, R. (2007), Evidence of slowing yield growth the example of Swiss cereal yield. Agri-Food and AgriEnvironmental Economics Group, ETH Zurich, Switzerland.

[8] HAMMED, L. A., ANIKWE, J. C \& ADEDEJI, A. R (2008) Cashew nuts and production development in Nigeria. American -Eurasian Journal of scientific research 3(1)54-61.

[9] IBRAHIM, F. D., MOHAMMED, U. S, NMADU, J. N, YAKBU, I. T AND IBRAHIM P. A (2010) Forecasting and Growth trend of sugarcane production: meeting the goals of commercial agriculture in Nigeria. A paper presented at the Nigeria Association of Agricultural Economics

[10] KARIM, M. R., M. A. AWAL AND M. AKTER, (2010). Forecasting of wheat production in Bangladesh. Bangladesh
Journal of Agricultural. Research, 35: 17-28.

[11] KHIN, A. A., EDDIE, C. F. C., SHAMSUNDIN, M. N., \& MOHAMED, Z. A. (2008, June 15-19).Natural]Price Forecasting in the World Market, Agricultural Sustainability Through Participate Global Extension, University Putra Malaysia, Kuala Lumpur, Malaysia

[12] NAZIR, M, AKHTAR W, AKMAL N AND BATOOL, S. (2016) Export forecasting of major fruit crops of Pakistan Science, Technology and Development 35(4) 148-152

[13] OLAGUNJU, F. I (2015) Comparative Advantage and Competitiveness of Cashew Crop in Nigeria: The Policy Analysis Matrix. International Journal of Agriculture and Economic Development, 3(1), 1-14.

[14] RAJAN, M. S., PALANIVEL, M., \& MOHAN, S K. (2015) Forecasting of Cotton Area, Production and Productivity using Trend analysis. International Journal for Research in Applied Science \& Engineering Technology (IJRASET) 3 (XII) 516520 .

[15] RAMAKRISHNA, G. MUKHERJEE, D. N., SRIKANTH, B AND BHAVE, M. HV (2014). Modelling rice production and forecasting in Andhra Pradesh. progressive Research 9 (conf. sept) $1200-1203$

[16] RIMI, R. H., S. H. RAHMAN, S. KARMAKAR AND S. G. HUSSAIN, 2009. Trend analysis of climate change and investigation on its probable impacts on rice production at Sathkhira, Bangladesh. Pakistan Journal of Meteorology, 6:3750 .

[17] SANDIP S. (2013) Trend analysis and forecasting coconut production in Assam. Journal of plantain crops. 41(2) 238-241

[18] SRINIVASA RAO, V AND SRINIVASULU, R. (2006). Growth comparisons of turmeric up to 2020 AD. The Andhra Agricultural Journal. 53(1\&2): 108-109.

[19] TAHIR, A. S \& AMRAN, A (2013), forecasting of maize area and production in Pakistan. E Sci Journal of Crop Production. 02 (02). 44-48.

[20] TUNJ, A. (2013). Farmer's Response to Agricultural Prices in India: A study in decision making, Heritage Publishers. 